\title{
The organizational architecture of entrepreneurial universities across the stages of entrepreneurship: a conceptual framework
}

\author{
James A. Cunningham (D) Erik E. Lehmann • \\ Matthias Menter
}

Accepted: 10 May 2021 / Published online: 17 June 2021

(C) The Author(s) 2021

\begin{abstract}
Entrepreneurial universities contribute directly and indirectly to supporting all stages of entrepreneurship. The challenge for entrepreneurial universities is how they can best support academic entrepreneurs through these stages of entrepreneurship. This has led to the creation of different and often ad hoc organizational units within an entrepreneurial university. The organizational challenge for entrepreneurial universities is the selection of the appropriate formal organizational architecture to support the stages of entrepreneurship. The purpose of this paper is to examine the organizational architecture of entrepreneurial universities and how it supports the stages of entrepreneurship - latent, emergent, launch, and growth. Our conceptual organizational framework
\end{abstract}

J. A. Cunningham $(\bowtie)$

Newcastle Business School, Northumbria University, Newcastle upon Tyne, UK

e-mail: james.cunningham@northumbria.ac.uk

\section{J. A. Cunningham}

Centre for Innovation Research (CIRCLE) Lund

University, Lund, Sweden

\section{E. E. Lehmann}

Faculty of Business and Economics, University

of Augsburg, Augsburg, Germany

e-mail: erik.lehmann@wiwi.uni-augsburg.de

\section{Menter}

Faculty of Economics and Business Administration, Friedrich Schiller University Jena, Jena, Germany

e-mail: matthias.menter@uni-jena.de conflates the stages of entrepreneurship with the actual needs of university-based entrepreneurs and how these needs are supported through different formal organizational units within the organizational architecture of entrepreneurial universities. Therein, we categorize three types of formal organizational units - those that focus on exploration stages of entrepreneurship, those that straddle exploration and exploitation stages of entrepreneurship, and those that boundary span all stages of entrepreneurship. We conclude by discussing the resultant organizational tensions for entrepreneurial universities and highlight future avenues of research.

Plain English Summary One of the challenges that managers of entrepreneurial universities face relates to the necessary formal organizational structures that are needed to be put in place to support universitybased entrepreneurs and meet their actual needs across the stages of entrepreneurship (latent, emergent, launch, and growth). We categorize three types of formal organizational units - those that have an exclusive focus on exploration stages of entrepreneurship, those that have a selective focus on exploration and exploitation stages of entrepreneurship, and those that have an overarching focus on all exploration and exploitation stages of entrepreneurship. We further highlight some organizational tensions as a result of these configurations that entrepreneurial university managers have to handle. Such tensions relate to 
resource, skill, and competence synergies, seamless organizational support for university-based entrepreneurs across the different stages of entrepreneurship, appropriate governance structures, alignment of organizational units with the wider entrepreneurship context, and the appropriate configuration and mix of organizational units to support the stages of entrepreneurship.

Keywords Entrepreneurial universities ·

Organizational architecture $\cdot$ Latent

entrepreneurship · Emergent entrepreneurship ·

Entrepreneurship · University-based entrepreneurs ·

Entrepreneurial ecosystems

\section{JEL classifications $\quad \mathrm{L} 26 \cdot \mathrm{O} 31 \cdot \mathrm{O} 32$}

\section{Introduction}

Whereas traditional universities are viewed as archetypal self-administrative static organizations with a focus on knowledge creation for its own sake, entrepreneurial universities have expanded the traditional university missions of teaching and research and have put emphasis on third mission activities to commercialize newly created knowledge through entrepreneurial activities. This transformation implies that entrepreneurial universities also need to adapt an entrepreneurial culture that is reflected in their structures and governance (see Guerrero et al., 2014). Entrepreneurial universities are crucial institutions fostering economic growth, innovation capabilities, and regional competitiveness (see Audretsch et al., 2012; Guerrero et al., 2016), and enhancing entrepreneurship capital within the region (Audretsch, 2014; Goldstein, 2010). One of the roles of entrepreneurial universities is to stimulate and nurture entrepreneurship among different organizational stakeholders (Klofsten et al., 2019). Previous studies of entrepreneurial universities have consistently highlighted the important role they play in supporting entrepreneurship (see Duruflé et al., 2018; Audretsch et al., 2016; Klofsten, 2000; Nurmi \& Paasio, 2007; Hannon, 2013; O'Reilly et al., 2019; Matlay, 2008; Cunningham \& Menter, 2021; Graf \& Menter, 2021; Wagner et al., 2021). From an entrepreneurial university perspective, one of the key challenges relates to appropriate formal organizational structures that meet the actual needs of university-based entrepreneurs across the different stages of entrepreneurship - latent, emergent, launch, and growth (Caiazza et al., 2020). In essence, the challenge for entrepreneurial universities is to ensure that the organizational architecture fits into the changing "strategy-environment" context (see Parakhina et al., 2017). A crucial questions thereby relate to how the entrepreneurial university architecture is meeting the needs of university-based entrepreneurs over the stages of entrepreneurship and how responsive it is to dealing with changes in the external environment. This in turn means that entrepreneurial universities need to consider how to best structure their formal entrepreneurship and innovation supports (see Dooley \& Kirk, 2007) as well as how to deal with the drivers of change that directly impact such supports across the stages of entrepreneurship (see Miller et al., 2021).

While much research has been devoted to the importance of entrepreneurial universities as sources of generating knowledge, educating students, and transferring knowledge and human capital to the society (see Forliano et al., 2021; Belitski et al., 2021), there is only limited research that examines organizational structures and governance within entrepreneurial universities (see Donina et al., 2017). Specifically, there is a paucity of research focusing on the formal organizational architecture and structures of entrepreneurial universities across the stages of entrepreneurship. Consequently, the purpose of this paper is to develop an organizing conceptual framework that identifies the needs of university-based entrepreneurs across the different stages of entrepreneurship and how these are supported through formal organizational units within the organizational architecture of an entrepreneurial university. Further to that, we identify some of the organizational challenges and tensions for entrepreneurial universities that emanate from organizational architectures. Implementing an organizational architecture requires the combination and orchestration of different organizational units to holistically support entrepreneurial endeavors the entrepreneur and the entrepreneurial process whereby the associated organizational culture provides some of the appropriate conditions and supports for the different stages of entrepreneurship (Cunningham et al., 2017a).

The remainder of our paper is structured as follows. "Section 2" provides a review of the literature 
on entrepreneurial universities and their organizational architecture units as well as examines the different stages of entrepreneurship. "Section 3" outlines our conceptual framework. "Section 4" highlights the resultant organizational tensions for entrepreneurial universities. A final section concludes and provides future avenues of research.

\section{Literature review}

\subsection{Entrepreneurial universities}

Current research has reframed the role of universities for the economy and society (see Gunasekara, 2006; Carl \& Menter, 2021) and has redefined the three main tasks of universities, namely, academic teaching, research, and the transmission towards society (see Etzkowitz et al., 2000; Graf \& Menter, 2021). While universities, like almost all other institutions, are generally defined by their boundaries, they are also open social systems. Entrepreneurial universities are catalysts for economic and societal change (Markuerkiaga et al., 2014), whereby the creation of an entrepreneurial university takes time and requires less of a top down approach (see Bratianu \& Stanciu, 2010). Hierarchical structures coupled with control, corporate culture, and rewards are some of the barriers that prevent universities from becoming an entrepreneurial university (Kirby, 2006). To encourage universities to transform to become entrepreneurial universities, national governments have created policies and incentives for institutions to accelerate this transformation. Some examples include the Excellence Initiative in Germany (see Menter et al., 2018; Civera et al., 2020; Kuratko \& Menter, 2017), the Higher Education Fund in the UK (see Washer, 2007; Siegel et al., 2003b), and the Programme for Research in Third Level Institutions in Ireland (see Cunningham \& Golden, 2015).

Transforming to become an entrepreneurial university is thereby more than just putting in place funding and infrastructure but requires universities to become entrepreneurial in their culture and entrepreneurial behavior (Kirby, 2006). To achieve this, entrepreneurial universities must make changes to their organizational structures and culture that are aligned to their institutional values and national contexts (Kalar \& Antoncic, 2015). Like any organization, they must ensure the "strategy-environment-structure" fit (Bleiklie et al., 2017). Achieving sustained high performance in universities, like in business general, results from establishing and maintaining a fit among three core elements: (1) the strategy, (2) the environment, and (3) the organizational architecture (Roberts, 2004). Entrepreneurial universities support the transformation of knowledge and are involved in undertaking and realizing transfer activities (Guerrero \& Urbano, 2012). To realize this effectively on a sustainable basis, entrepreneurial universities need to have in place the optimal formal organizational architecture and structure that supports entrepreneurship across the stages of entrepreneurship.

\subsection{The organizational structure of entrepreneurial universities}

The issue of organizational structure in entrepreneurial universities has received limited research attention yet is critical in establishing and sustaining a university organizational culture that supports and fosters entrepreneurship (see Lazzeretti \& Tavoletti, 2005). Gibb and Hannon (2005) argue that the organizational structures of universities might stimulate or constrain entrepreneurship and entrepreneurial behavior within university communities. In essence, the organizational structures are created to enable individual actors within the university environment to pursue and realize entrepreneurial opportunities. The entrepreneurial spirit of entrepreneurial universities thereby comes from universities' central structures and where, as Bratianu and Stanciu (2010:125) describe it, "people innovate on the education and research level in order to exist and develop." Clark (2001) describes this as "a steering core" that attempts to combine in a more effective way individual departments and the centralization of universities. Organizational governance, transfer, and infrastructure have thereby been identified as the different elements of entrepreneurial university structures (see Bronstein \& Reihlen, 2014).

Moreover, Etzkowitz (2003) compares the elements of an entrepreneurial university to that of a start-up whereby the expansion of the university 
mission focus has changed the primary organization mode of "professor-student dyads." One of the challenges he identified is having in place appropriate organizational mechanisms and guidelines that can mitigate against conflicts of interest. Kirby (2006) argues that for universities to become entrepreneurial, they must put in place a more permanent infrastructure rather than just relying on incentives to support the transition. Preparing future entrepreneurs and being entrepreneurial itself are the two main tasks of entrepreneurial universities (Schulte, 2004). Formica (2002:174) goes further and suggests that "entrepreneurial universities are intellectual infrastructures that lead to the formation of new ventures which do not remain small businesses for long. They offer innovative learning settings and hands-on experience inside operating businesses, thereby encouraging more people to become literate in entrepreneurship." Guerrero et al. (2014), in their comparative study of Spanish and Irish universities, find two distinct organizational structures - collegial and streamlined — as one of the conditioning factors of an entrepreneurial university.

Drawing on the corporate entrepreneurship literature, Nelles and Vorley (2010) take an entrepreneurial university architecture perspective and identify five internal factors with one being structure, which they classify as "formal" units, that are tasked with supporting third mission activities such as technology transfer offices and incubators. Other factors they identify include systems, leadership, strategies, and culture arguing that these internal factors all overlap (see Vorley \& Nelles, 2009). Using a case study of the University of Oxford, Nelles and Vorley (2008) argue that the entrepreneurial architecture is built on institutional strengths and that there is mission integration of third stream activities that are conflated with teaching and research. Furthermore, Martin et al.'s (2019) study of UK universities highlights that an entrepreneurial architecture needs to embed a social architecture. Middle managers at the meso level (such as deans and heads of department) are critical actors in influencing and supporting entrepreneurship and innovation activities within an entrepreneurial architecture, particularly given the top down and unidirectional approaches adopted by entrepreneurial universities (Beresford \& Michels, 2014).
2.3 The organizational units of entrepreneurial universities

While literature on the organizational architecture of entrepreneurial universities is still in its infancy, there have been numerous studies that have examined different organizational units that support entrepreneurs and contribute to regional growth and competitiveness (see Audretsch et al., 2005). Universities have thereby been seen as focal institutions within an innovation ecosystem, with a strategic focus towards universityindustry relationships (see Lehmann \& Menter, 2016). The architectural design that has attempted to respond effectively to ensuring the "strategy-environmentstructure" fit has led to the creation and development of a variety of organizational units within entrepreneurial universities to support the stages of entrepreneurship. Such organizational units include the establishment of technology transfer offices (Siegel et al., 2003a), entrepreneurship centers (Maas \& Jones, 2017), entrepreneurship research centers (Cassia et al., 2014), cooperative research centers (Boardman \& Gray, 2010), proof-of-concept centers (Hayter \& Link, 2015), incubators (Mian, 1996, 1997), accelerators (Pauwels et al., 2016), science parks (Link \& Scott, 2015), and new faculties and departments with a strong focus on technology transfer and innovation.

In tandem with the growth of organizational units to support the stages of entrepreneurship, entrepreneurial universities have responded by expanding their entrepreneurial education through new programs and modules across the university (Nicotra et al., 2021). Integrating entrepreneurship and the concepts of entrepreneurship are seen as the raison d'etre and a main purpose of universities in revisiting their strategy and designing the university architecture (Swaen et al., 2011). Hence, fostering entrepreneurial orientation and behavior, establishing an entrepreneurial attitude, and acting as collective entrepreneurs moved on the agenda of universities.

\subsection{The stages of entrepreneurship}

Within the entrepreneurship field, there is a renewed interest in the stages of entrepreneurship (see Khurana \& Dutta, 2021; Cunningham \& Link, 2021). Within this literature, there are different interpretations of the stages of entrepreneurship (see Gaibraith, 
1982; Levie \& Lichtenstein, 2010; Littunen \& Niittykangas, 2010; Santos et al., 2010). For example, from a firm level perspective, Lewis and Churchill (1983) identified five stages of firm development - existence, survival, success, take-off, and resource maturity. From an individual perspective, these stages of entrepreneurship can be categorized into four phases - latent, emergent, launch, and growth (Caiazza et al., 2020). Latent and emergent stages are focused on the exploration of entrepreneurial opportunities whereas the launch and growth phases are focused on the exploitation thereof.

Whereas latent forms of entrepreneurship describe the conditions that entrepreneurial potential and opportunities are existent but not perceived as such and consequently not exploited, emergent forms of entrepreneurship refer to the actual recognition and willingness to commercialize new knowledge (see Blanchflower et al., 2001; Caiazza et al., 2020; Masuda, 2006; Belitski et al., 2021). In essence, Freytag and Thurik (2007:124) best describe latent entrepreneurship as individuals who "want to be an entrepreneur." This stage of entrepreneurship has been measured using an individually declared preference of being self-employment over being employment (see Grilo \& Thurik, 2005).

Emergent entrepreneurs can be defined as individuals who are actively involved in attempting to start a venture (see Wennekers et al., 2005). ${ }^{1}$ Emergent entrepreneurs build on what Lichtenstein et al. (2007) term "momentum" in undertaking different tasks and activities that will enable the establishment of a new venture. These activities and tasks are action orientated towards exploring entrepreneurial opportunities, building the breeding ground for the subsequent exploitation thereof (Audretsch, 2012; Hechavarria et al., 2012). The activities could include among others structured or unstructured market research, financial planning, and business model development. According to Davidsson and Honig (2003), these are gestation activities.

The next two stages of entrepreneurship move from the exploration of an entrepreneurial opportunity to

\footnotetext{
1 Wennekers et al. (2005) utilize the term "nascent entrepreneurship," which has large overlaps with the concept of "emergent entrepreneurship" or can even be interpreted as a synonym, as both concepts are focusing on the early stages of starting a new venture.
}

its exploitation. During the launch phase, the entrepreneurs combine their resource base and their team to launch their venture (Brush et al., 2001; Herron \& Sapienza, 1992) to exploit the identified entrepreneurial opportunity. This involves entrepreneurial risk and the individual entrepreneur making decisions about the effective deployment of resources to ensure that the new venture survives (see Norton \& Moore, 2002; Walsh \& Cunningham, 2016). During this phase, entrepreneurs have to cope with capital and experience constraints (see Van Auken, 1999) as well as have to cope with competitor responses to their entry and presence at the market place.

The final stage is growth where the new venture has established its financial and market viability in the exploitation of entrepreneurial opportunities. The entrepreneurs' efforts thereby focus on continuing to exploit the original entrepreneurial opportunity and can also shift to exploiting new ones that may have been identified through their market place presence and operations. Entrepreneurs at this stage have different growth aspirations that are influenced by environmental and institutional factors, such as government regulation or intellectual property protection (see Autio \& Acs, 2010; Basu \& Goswami, 1999; Estrin et al., 2013).

In summary, entrepreneurial universities have to cope with and manage a variety of drivers of change (see Miller et al., 2021) while also ensuring that they effectively support university-based entrepreneurs across the different stages of entrepreneurship, thereby fulfilling their third mission. Some of the activities will have spillovers into the regional and national environments (Acs et al., 2013; Audretsch et al., 2014, 2015). The challenge for the entrepreneurial university then is to design an organizational architecture to achieve the best performance that matches and meets the identified needs of universitybased entrepreneurs across the stages of entrepreneurship while also supporting and contributing to entrepreneurship and innovation outside of the formal organizational structures of an entrepreneurial university.

So the question relates to what the appropriate formal organizational architecture might be that entrepreneurial universities need to adapt that addresses strategy and the environment fit as well as effectively supports the stages of entrepreneurship (see Roberts, 2004). Consideration has to be given to the informal 


\begin{tabular}{|c|c|c|c|c|c|c|}
\hline \multirow{2}{*}{\multicolumn{3}{|c|}{ STAGES OF ENTREPRENEURSHIP }} & \multicolumn{2}{|c|}{ EXPLORATION } & \multicolumn{2}{|c|}{ EXPLOITATION } \\
\hline & & & Latent & Emergent & Launch & Growth \\
\hline \multicolumn{3}{|c|}{$\begin{array}{l}\text { MOTIVATIONS AND NEEDS } \\
\text { (Illustrative) }\end{array}$} & $\begin{array}{l}\text { - Exploring } \\
\text { entrepreneurial oppor- } \\
\text { tunities and potential } \\
\text { - Self-Employment } \\
\text { - Raising awareness }\end{array}$ & 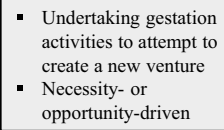 & $\begin{array}{l}\text { - Assembling resources, } \\
\text { team and networks } \\
\text { - Go to market } \\
\text { - Intellectual property } \\
\text { protection }\end{array}$ & 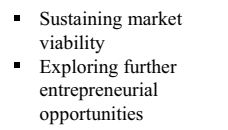 \\
\hline \multicolumn{3}{|c|}{$\begin{array}{l}\text { ACTIVITIES AND SUPPORTS } \\
\text { (Illustrative) }\end{array}$} & $\begin{array}{l}\text { - Entrepreneurship } \\
\text { education (tailored) and } \\
\text { familiarization } \\
\text { - Orientation programs }\end{array}$ & $\begin{array}{ll}\text { - } & \text { Market validation } \\
\text { - Business model } \\
\text { development } \\
\text { - Financial planning }\end{array}$ & $\begin{array}{l}\text { - IP agreements } \\
\text { - Securing seed/angel } \\
\text { funding } \\
\text { - Recruiting talent }\end{array}$ & $\begin{array}{ll}\text { - } & \text { Secondary funding } \\
\text { - } & \text { Networking events } \\
\text { alumning networks - }\end{array}$ \\
\hline \multirow{8}{*}{ 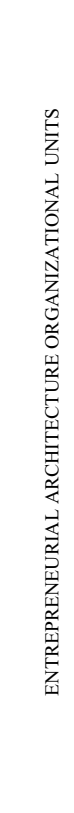 } & \multirow{2}{*}{ 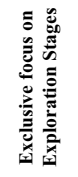 } & $\begin{array}{l}\text { ENTREPRENEURSHIP } \\
\text { RESEARCH CENTER }\end{array}$ & 4 & & & \\
\hline & & ENTREPRENEURSHIP CENTER & & & & \\
\hline & \multirow{4}{*}{ 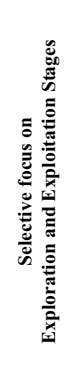 } & $\begin{array}{l}\text { COOPERATIVE RESEARCH } \\
\text { CENTER }\end{array}$ & & & & \\
\hline & & PROOF-OF-CONCEPT CENTER & & & & \\
\hline & & INCUBATOR & & & & \\
\hline & & ACCELERATOR & & & & \\
\hline & \multirow{2}{*}{ 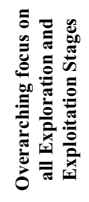 } & $\begin{array}{l}\text { TECHNOLOGY TRANSFER } \\
\text { OFFICE }\end{array}$ & & & & \\
\hline & & SCIENCE PARKS & & & & \\
\hline
\end{tabular}

Fig. 1 A conceptual framework of the organizational architecture of entrepreneurial universities across the stages of entrepreneurship

consequences - intended and unintended - of formal organizational unit configurations in contributing to and supporting the stages of entrepreneurship within an entrepreneurial university. Therefore, entrepreneurial universities need to formulate their strategies, with a focus on the design perspective, to create an organizational architecture in the light of the wider entrepreneurial environment they inhabit (see Belitski \& Heron, 2017).

\section{A conceptual organizing framework}

Given the fragmentation in the literature with regard to entrepreneurial universities and their respective formal organizational units that support universitybased entrepreneurs, our conceptual organizing framework addresses the actual needs of entrepreneurs across the stages of entrepreneurship. It also responds to growing economic and societal demands and expectations of stakeholders on entrepreneurial universities, particularly with regard to contributing consistently to economic growth and wealth creation. Figure 1 summarizes the outlined relationships between the stages of entrepreneurship, the motivation and needs of university-based entrepreneurs, and the organizational architecture units of an entrepreneurial university. 
3.1 The needs of entrepreneurial university-based entrepreneurs

Entrepreneurial university-based entrepreneurs are typically and predominately drawn from the university community: students, graduates, and faculty (Larsson et al., 2017; Li et al., 2018; Miller et al., 2018; Morris et al., 2017). Some entrepreneurs are also drawn from outside the entrepreneurial university and join university community members in cofounding new ventures. All of these university-based entrepreneurs have different needs over the stages of entrepreneurship. The challenge for entrepreneurial universities is how to best address the actual needs of university-based entrepreneurs during these stages.

In the latent and emergent stages of entrepreneurship, university-based entrepreneurs are grappling and struggling with whether they want to become an entrepreneur (Murnieks et al., 2014). Also, there is identity modification that is associated with being a university-based entrepreneur, particularly during these stages, adopting a hybrid role identity of an academic and an entrepreneur (Jain et al., 2009; O'Kane et al., 2020). It is about exploring and developing an entrepreneurial mindset that enables entrepreneurs to move from the exploration stages to the exploitation stages (see Haynie et al., 2010; Ucbasaran et al., 2003). Also, individual motivations and entrepreneurial behaviors are factors that influence universitybased entrepreneurs at the latent and emergent stages (see McAdam \& Cunningham, 2019), whereby the motivation can be necessity or opportunity driven (see Carsrud \& Brännback, 2011). In identifying potential entrepreneurial opportunities, these entrepreneurs first need to validate these opportunities to better understand the viability and potential in order to then make a decision to launch a new venture. University-based entrepreneurs thus need to get an understanding of themselves and the nature and process of entrepreneurship and being an entrepreneur as well as need to develop an entrepreneurial idea.

The exploitation stages of entrepreneurship are focused on going through the formal stages of company formation, getting products or services into the market, securing capital, building the entrepreneurial team, refining the business model, and implementing strategy (Baum, 1995; Morris et al., 2005). Their learning needs are very particular and require different interventions that contribute to their growth aspirations (Sexton et al., 1997) they tend to have, according to Gundry and Welsch (2001), "a more structured approach to organizing their business which suggests a more discipline perception of managing the firm." Supporting the growth ambitions of entrepreneurs particularly at the growth stage can increase the probability of further realized growth (Delmar \& Wiklund, 2008). Davidsson (1989) found that there is a positive relation between achievement and growth willingness for growth-oriented entrepreneurs. During this exploitation phase, these entrepreneurs need to draw on networks to support their new ventures, such as alumni networks (Berggren, 2017). However, university-based entrepreneurs face barriers in exploiting their opportunities (Davey et al., 2016; O'Kane et al., 2017) and also often have skill, expertise, and competence gaps. Therefore, they require access to a variety of formal and informal supports to overcome barriers and meet skill, expertise, and competence gaps (De Silva, 2016; Moog et al., 2015). In the subsequent section, we turn our attention to the organizational units within an entrepreneurial university that support the different stages of entrepreneurship. We have identified three different types of organizational units that support the different stages of entrepreneurship based on their mission scope and focus.

\subsection{Organizational units: exclusive focus on exploration stages of entrepreneurship}

For the exploration phases - latent and emergent - the starting point of the design process of an organizational architecture within an entrepreneurial university is to raise the awareness of the needs and demands of entrepreneurs, exploring what entrepreneurship comprises. The predominant mission focus and scope during these stages is to nurture potential entrepreneurs and to support their ideation in tandem with providing knowledge about the entrepreneurial process and the nature of entrepreneurship. The focus is on the individual, the potential to become an entrepreneur and also the process of entrepreneurship. Consequently, the organizational architectural features contain elements raising the awareness of entrepreneurship and nurturing entrepreneurial behavior and orientation. 
Nominating professors with a focus on entrepreneurship and curriculums with a focus on entrepreneurship can constitute a first step by an entrepreneurial university but that does not shape the organizational architecture significantly. Therefore, formal organizational units as part of the entrepreneurial university architecture need to complement these activities. Some of these formal organizational units at the latent and emergent stages of entrepreneurship include entrepreneurship research centers (ERCs) and entrepreneurship centers (ECs).

ERCs' dedicated mission focus and scope is towards linking entrepreneurship research to education and is very diverse (see Sandberg \& Gatewood, 1991). According to Cassia et al. (2014), ERCs can be classified into three distinct groups - pure ERCs, educational ERCs, and multi-service ERCs. ERCs are organizational units with a formal governance structure, defined vertical and horizontal boundaries, with the purpose to raise and increase the awareness of entrepreneurial behavior and the need for entrepreneurial thinking. Multi-service ERCs' focus and remit is typically focused on the exploration of entrepreneurial opportunities and the support for latent and emergent entrepreneurs with respect to developing an entrepreneurial mindset and transmitting experiential knowledge and knowhow about the entrepreneurial experience (see Cassia et al., 2014). Pure ERCs can support policy development and can enhance the general awareness of entrepreneurial activities when their research is carried out in the region they are located in. Educational orientated ERCs usually run a variety of program offerings tailored to different entrepreneurial groups that can be integrated in the core curriculum or as part of extracurricular activities such as business plan competitions (see Watson et al., 2018).

ECs also play both a direct and indirect role in stimulating entrepreneurial activities, on the one hand through communicating own programs and activities and on the other hand through initiating joint interdisciplinary activities (Maas \& Jones, 2017). ECs' mission focus and scope is to encourage and nurture entrepreneurship and offer business and educational services, especially for students and graduates (Menzies, 2000). Collectively, both organizational units contribute to gestation activities of latent and emergent entrepreneurs.

\subsection{Organizational units: selective focus on exploration and exploitation stages of entrepreneurship}

Entrepreneurial universities have created formal organizational units that straddle between exploration and exploitation stages of entrepreneurship. Such formal organizational units include cooperative research centers (CRCs), proof-of-concept centers (PoCCs), incubators, and accelerators. These organizational units meet a combination of needs of entrepreneurs and particularly support their gestation needs through activities devoted to market validation, business model development, and planning. Other entrepreneurs may have moved beyond the exploration stages and may have made a decision to become an entrepreneur and formally start the new venture formation process. Therefore, the activities and supports reflect their needs during either the launch and growth phases or both.

CRCs support both the exploration and exploitation of entrepreneurial opportunities. Their establishment as a formal organizational unit was born out of the need to commercialize more research through entrepreneurship, technology, and knowledge transfer. According to Boardman and Gray (2010), CRCs' mission focus and scope is to engage in research, exhibit organizational formality, and promote organizational and cross-sector collaboration and transfer. Typically, CRCs involve industry, government, and universities and facilitate collaborations that are individually and mutually beneficial to all stakeholders and are involved in new venture formation (Boardman \& Gray, 2010). In studying Australian CRCs, Garrett-Jones et al. (2010) found that these institutions helped scientists to develop entrepreneurial skills and acquire knowledge about market opportunities and industry engagement. Furthermore, Dolan et al. (2019), taking a micro level approach, found that CRCs focus on supporting research quality enhancement, brokerage, networks and collaboration, resource enhancement, and appropriation.

PoCCs are defined by Hayter and Link (2015: 179) as "an organizational innovation that specifically focuses on challenges associated with commercializing university technology, including lack of access to resources, services, and networks 
that support the development of university startups." PoCCs constitute a critical technology infrastructure and accelerate the advancement of ideas and prototypes into marketable products (Bradley et al., 2013). Thus, the main mission task of PoCCs is the provision of adequate resources for entrepreneurs at the emergent and launch stages of entrepreneurship.

Incubators are designed to especially support the latent, emergent, and launch stages of entrepreneurship by providing access to initial funding and offering specific services that are meant to reduce time-tomarket and expanding the network of founders (see Grimaldi \& Grandi, 2005). In particular, incubators can provide tangible resource support, especially angel and seed capital (see Aernoudt, 2004), to entrepreneurs at the launch stage. According to Bergek and Norrman (2008), incubators compose of three core elements - selection, business support, and mediation. Schulte (2004) argues that incubators within entrepreneurial universities are a manifestation of how they conduct themselves in an entrepreneurial way.

In more recent years, accelerators have become a more prominent organizational unit within entrepreneurial universities. Accelerators have been developed from incubators over the last decade, with a stronger mission focus on service activities like "training-on-the-job" as an entrepreneur and connecting the entrepreneurial teams with key players from the entrepreneurial ecosystem. Accelerators typically consist of program packages, a strategic focus, a selection process, a funding structure, and an alumni relations model (Pauwels et al., 2016). Hausberg and Korreck (2020:160) describe accelerators as "fixed-term, cohort-based programs providing education, monitoring, and mentoring to startup teams (usually not single entrepreneurs) and connecting them with experienced entrepreneurs, venture capitalists, angel investors and corporate executives and preparing them for public pitch events." Educational components are also part of accelerators, whereby knowledge is typically delivered through seminars with mentorship provided over a number of months. These seminars are usually targeted at entrepreneurs at the emergent and launch stages of entrepreneurship (Cohen \& Hochberg, 2014).
3.4 Organizational units: overarching focus on all exploration and exploitation stages of entrepreneurship

Boundary spanning formal organizational units attempt to meet the needs of entrepreneurs through all stages of entrepreneurship. As such, entrepreneurial universities have established specific technology transfer offices (TTOs) and science parks as formal organizational units that span across. Such organizational units draw on external expertise through local and regional networks as well as alumni.

TTOs' mission focus has expanded beyond just protecting the intellectual property of entrepreneurial universities. TTOs are designed to support and protect the ideas, inventions, and innovations of academic researchers, transferring them to the (regional) industry and society (Hülsbeck et al., 2013). TTOs thereby holistically cover all stages of entrepreneurship as they do not only provide information and support during market validation but also shape and guide the patenting and licensing processes (Cunningham et al., 2020). According to Fitzgerald et al. (2021:73), TTOs provide "a wide range of complementary services such as supporting spin-outs, entrepreneurship training and industry outreach programs." The same holds true for science parks that also provide support for the different stages of entrepreneurship. Link and Scott (2015:169) define science parks as "a type of public-private partnership that fosters knowledge flows - often between park firms and universities and among park firms - and contributes to regional economic growth and development." Science parks support new venture creation, technology development, R\&D links with universities, and science park firms as well as host incubators and accelerators (see Albort-Morant \& Ribeiro-Soriano, 2016; ArroyoVazquez \& van der Sijde, 2008; Clark, 2003; Massey \& Wield, 2003; Phan et al., 2005). Consequently, science parks can provide support for entrepreneurs across all stages of entrepreneurship.

\section{Organizational tensions}

The proliferation of organizational units designed to support the stages of entrepreneurship within entrepreneurial universities reflect their mission expansion (Miller et al., 2021). Such an expansion of the 
organizational architecture can create new organizational tensions and fault lines.

First, instead of achieving resource, skill, and competence synergies and complementarities, organizational units might duplicate resources and provide similar supports and activities that meet the needs of entrepreneurs at the same stage of entrepreneurship. In essence, this could lead to situations where different organizational units are competing intensely to attract university-based entrepreneurs that have the best potential and/or where different organizational units are supporting individuals within the university community that have no real intention of going further than one stage of entrepreneurship. The provided support might thereby be an end in itself, where organizational units might only offer activities for the sake of it to demonstrate the necessary organization activity and throughput without advancing an individual through to the next stage of entrepreneurship. This issue is tied to attribution and how organizational units are measured in relation to their performance by the university management teams and university-based stakeholders as well as other actors within an ecosystem. Depending on measurement metrics and attribution, organizational units might attempt to game the organization performance system for their own ends, irrespective of the needs of individual university-based entrepreneurs.

A second tension relates to creating seamless organizational support for university-based entrepreneurs through the different stages of entrepreneurship on the one hand and creating individual organizational unit governance structures, cultures, and processes on the other hand that might ultimately prevent easy support transition between the different stages of entrepreneurship within an entrepreneurial university. With established and autonomous or semi-autonomous organizational units, no formal and informal collaboration among units might exist in order to act in the best interests of university-based entrepreneurs rather than in the self-interest of the respective organizational unit. In such situations, it may mean that university-based entrepreneurs are not well served by organizational units that have a myopic focus on their own institutional survival instead of meeting their actual needs. However, seamless integration of organizational units is necessary in order to best support the actual needs of university-based entrepreneurs across or at different stages of entrepreneurship. Such transitions for university-based entrepreneurs can be difficult given role identity transitions (see Jain et al., 2009; O'Kane et al., 2020) and this may also unintentionally create further barriers for university-based entrepreneurs rather than removing them.

A third source of tension concerns the appropriate governance structures to put in place that balance the freedom of organizational units to be flexible in their provision of supports to meet university-based entrepreneurs' needs while also ensuring that wider entrepreneurial university governance and norms are adhered to and followed. The tension pertains to balancing the level and types of autonomy against the necessary wider organizational and institutional controls. In order to manage this tension from an organizational structure perspective, autonomy needs to be balanced centrally or devolved down to the faculties and departments. It will also depend on wider entrepreneurial and innovation ecosystems that entrepreneurial universities engage in and the current and future needs of entrepreneurs across the stages of entrepreneurship.

A fourth tension is the internal alignment of organizational units with the wider entrepreneurship context. Organizational units need to naturally allow for wider ecosystem stakeholder engagement outside their entrepreneurial university institutional boundaries. These organizational units need to draw on the expertise and natural support of other entrepreneurial and innovation ecosystem actors within the context of the entrepreneurial university. The tension may arise with respect to the blurriness of mission focus between organizational units, the entrepreneurial university, and against the wider demands of ecosystem actors.

A fifth source of tension relates to the appropriate configuration and mix of organizational units to support the stages of entrepreneurship within different forms of entrepreneurial and innovation ecosystems. There is a danger of crowding out and organizational units overlapping due to the proliferation of organizational units. Entrepreneurial universities may create such units in a herd like manner to be seen to have these units as they are seen to be required to support entrepreneurs within different forms of entrepreneurial and innovation ecosystems. This then raises the broader questions of resources, organizational legitimacy, and visibility that address the appropriateness of organizational units within entrepreneurial 
universities supporting university-based entrepreneurs through the different stages of entrepreneurship irrespective of entrepreneurial and innovation ecosystems characteristics and configurations.

\section{Conclusion and future avenues of research}

Against the backdrop of the fragmented and burgeoning nature of the body of entrepreneurial university research, we have identified three types of formal organizational units across the stages of entrepreneurship. These are organizational units that focus exclusively on exploration stages of entrepreneurship, those that straddle exploration and exploitation stages of entrepreneurship, and those that boundary span all stages of entrepreneurship. In this context, we have identified the associated resultant tensions that can pervade the organizational architecture of entrepreneurial universities across the stages of entrepreneurship. Tensions center on synergies and complementarities, organizational independence and organizational unit independence, organizational unit autonomy and institutional control, internal and external environmental alignment, and organizational unit mix across the stages of entrepreneurship.

Our organizing conceptual framework leads to some strategic considerations for university leaders, policy makers, and funders. For university leaders, our organizing framework might provide an overarching strategic means that helps them to understand the configuration of organizational units to effectively support entrepreneurship and to consider how to manage some of our identified tensions. Such considerations can be used to implement an appropriate organizational architecture that complements and addresses wider entrepreneurial and innovation ecosystems needs. While we have focused on established organizational units, we would encourage university leaders, faculties, students, and graduates to develop new organizational units that meet more the inclusive needs of entrepreneurs across the stages of entrepreneurship. For policy makers, our framework might enable a better policy instrument development that supports entrepreneurial universities to create the appropriate configuration of an organizational architecture that meets the needs of entrepreneurs within the entrepreneurial university community and more generally supports placed-based entrepreneurship (see Grillitsch, 2018) within a variety of entrepreneurial and innovation ecosystems. For research funders, our framework might contribute to factor in entrepreneurial university organizational structures in the design of funding programs that are better designed to exploit new knowledge and have wider entrepreneurial and innovation ecosystem benefits (see Audretsch et al., 2019). Such schemes need to be improved to match the organizational architecture that entrepreneurial universities have in place to especially support the exploitation stages of entrepreneurship.

As an emergent strand of literature, our conceptual framework generates further questions some of which we have outlined in Table 1.

Future research should address these specific questions as well as others. Our conceptual framework provides the basis for further empirical investigations as well as opens up a debate about how entrepreneurial universities should best support university-based entrepreneurs using formal organizational units within different entrepreneurial and innovation ecosystems. While there has been a growth of these organizational units within entrepreneurial universities, a fundamental question remains as to whether these units and their current configurations within entrepreneurial universities really meet the needs of latent and emergent entrepreneurs as well as wider entrepreneurial and innovation ecosystem needs. In other words: Are existing organizational architectures and organizational units fit for purpose given the increasing demands being placed on entrepreneurial universities, particularly with respect to a place-based entrepreneurship perspective and economic wealth creation? Are there other organizational units that need to be developed that better meet current and future demands of university-based entrepreneurs and other entrepreneurial and innovation ecosystem entrepreneurs? Would the establishment of new organizational units thereby reflect shortcomings and failures of well-established organizational units such as TTOs? Are such organizational units embracing inclusive support for place-based entrepreneurship?

Future research should address these questions as it has significant policy and practice applications for how entrepreneurial universities operate and are managed within different entrepreneurial and innovation ecosystems. In addition, future research is necessary to examine the governance 
Table 1 Future avenues of research

\begin{tabular}{|c|c|}
\hline Themes & Research questions \\
\hline ontext & $\begin{array}{l}\text { - How does the external environment and entrepreneurial and innovation ecosystem (policy environment, technologi- } \\
\text { cal environment etc.) stimulate the creation of new organizational units within entrepreneurial universities? } \\
\text { - How do the capacities of entrepreneurial ecosystems influence the creation of new organizational units within entre- } \\
\text { preneurial universities? } \\
\text { - How does the organizational architecture of other ecosystem stakeholders affect the organizational architecture of } \\
\text { entrepreneurial universities? }\end{array}$ \\
\hline Strategy & $\begin{array}{l}\text { - How do entrepreneurial universities decide what organizational units to include as part of their entrepreneurial } \\
\text { architecture? } \\
\text { - How does strategy development take place within the organizational units of entrepreneurial universities across the } \\
\text { stages of entrepreneurship? } \\
\text { - How can the micro strategy of organizational units be aligned with the meso strategy of entrepreneurial universities } \\
\text { and the macro strategy and needs of entrepreneurial and innovation ecosystems? } \\
\text { - How do strategy artifacts affect the engagement with external entrepreneurial and innovation ecosystem stakehold- } \\
\text { ers? } \\
\text { - How does strategic posture respond to the needs of university-based entrepreneurs and to the needs/demands of the } \\
\text { entrepreneurial process? }\end{array}$ \\
\hline Resources & $\begin{array}{l}\text { - What criteria do entrepreneurial universities use to allocate resources to individual organizational units and how do } \\
\text { they measure their performance? } \\
\text { - How do organizational units acquire and allocate resources (financial, human capital, etc.)? } \\
\text { - How do organizational units build internal and external legitimacy to receive resources (e.g. funds)? What role do } \\
\text { intangible resources (reputation, skill sets, networks) play in this context? } \\
\text { - How do organizational units manage tensions in the context of resource acquisition/ allocation? } \\
\text { - How do organizational units select input resources, such as university-based entrepreneurs, ecosystem entrepreneurs } \\
\text { and ecosystem partners within and across the stages of entrepreneurship? }\end{array}$ \\
\hline Mechanisms & $\begin{array}{l}\text { - How effective are organizational units individually and collectively in supporting the stages of entrepreneurial } \\
\text { growth? } \\
\text { - How do informal routines, policies, and processes contribute to the success and sustainability of individual organiza- } \\
\text { tional units in entrepreneurial universities within and across the stages of entrepreneurship? } \\
\text { - How do organizational units support university-based entrepreneurs and the entrepreneurial process, both formally } \\
\text { and informally within and across the stages of entrepreneurship? } \\
\text { - Which governance modes most effectively support the delivery of organizational units as well as meeting and antici- } \\
\text { pating external ecosystem stakeholder needs and demands? } \\
\text { - Which control mechanisms are in place that guide the activities of organizational units and their internal stakehold- } \\
\text { ers relationship and with external ecosystem actors.? } \\
\text { How can synergistic outcomes be ensured and expedited among organizational units? And vice versa, how do natu- } \\
\text { ral overlaps of support do not lead to substitution effects? }\end{array}$ \\
\hline Impact & $\begin{array}{l}\text { - What impact do organizational units actually have on formally and informally supporting university-based entrepre- } \\
\text { neurs at the different stages of entrepreneurial growth? } \\
\text { - How are best practices, knowledge, and information shared among different organizational units and what is the } \\
\text { impact thereof? } \\
\text { - How is the entrepreneurial and innovation ecosystem affected by the architecture of entrepreneurial universities? } \\
\text { - How can it contribute to (collective) place-based value creation? } \\
\text { - How do organizational units cope with entrepreneurial failure? How does this affect their performance and impact? } \\
\text { - How do halo effects stimulate and enhance agency internally and externally among ecosystem stakeholders across } \\
\text { the stages of entrepreneurship? }\end{array}$ \\
\hline
\end{tabular}

and managerial modes of the organizational architecture of entrepreneurial universities at the individual organizational unit level and the institutional level, using cross-country data and applying qualitative and quantitative methods (see Cunningham et al., 2017b). A final strand of future research should focus on the managerial controls and incentives that are used to support and sustain such organizational units and the organizational architecture as a whole. Ultimately, such research would contribute to the potential enhancement of entrepreneurial universities and how they support the stages 
of entrepreneurship as well as the overall efficiency and effectiveness of such institutions.

Open Access This article is licensed under a Creative Commons Attribution 4.0 International License, which permits use, sharing, adaptation, distribution and reproduction in any medium or format, as long as you give appropriate credit to the original author(s) and the source, provide a link to the Creative Commons licence, and indicate if changes were made. The images or other third party material in this article are included in the article's Creative Commons licence, unless indicated otherwise in a credit line to the material. If material is not included in the article's Creative Commons licence and your intended use is not permitted by statutory regulation or exceeds the permitted use, you will need to obtain permission directly from the copyright holder. To view a copy of this licence, visit http://creativecommons.org/licenses/by/4.0/.

\section{References}

Acs, Z. J., Audretsch, D. B., \& Lehmann, E. E. (2013). The knowledge spillover theory of entrepreneurship. Small Business Economics, 41(4), 757-774.

Aernoudt, R. (2004). Incubators: Tool for entrepreneurship? Small Business Economics, 23(2), 127-135.

Albort-Morant, G., \& Ribeiro-Soriano, D. (2016). A bibliometric analysis of international impact of business incubators. Journal of Business Research, 69(5), 1775-1779.

Arroyo-Vazquez, M., \& van der Sijde, P. (2008). Entrepreneurship encouragement and business development support at universities and science parks: Proposal for a new conceptualization. Industry and Higher Education, 22(1), 37-48.

Audretsch, D. B. (2012). Entrepreneurship research. Management Decision, 50(5), 755-764.

Audretsch, D. B. (2014). From the entrepreneurial university to the university for the entrepreneurial society. The Journal of Technology Transfer, 39(3), 313-321.

Audretsch, D. B., Cunningham, J. A., Kuratko, D. F., Lehmann, E. E., \& Menter, M. (2019). Entrepreneurial ecosystems: Economic, technological, and societal impacts. The Journal of Technology Transfer, 44(2), 313-325.

Audretsch, D. B., Hülsbeck, M., \& Lehmann, E. E. (2012). Regional competitiveness, university spillovers, and entrepreneurial activity. Small Business Economics, 39(3), 587-601.

Audretsch, D. B., Lehmann, E. E., \& Menter, M. (2016). Public cluster policy and new venture creation. Economia $e$ Politica Industriale, 43(4), 357-381.

Audretsch, D. B., Lehmann, E. E., \& Paleari, S. (2015). Academic policy and entrepreneurship: A European perspective. The Journal of Technology Transfer, 40(3), 363-368.

Audretsch, D. B., Lehmann, E. E., \& Warning, S. (2005). University spillovers and new firm location. Research Policy, 34(7), 1113-1122.
Audretsch, D. B., Lehmann, E. E., \& Wright, M. (2014). Technology transfer in a global economy. The Journal of Technology Transfer, 39(3), 301-312.

Autio, E., \& Acs, Z. J. (2010). Intellectual property protection and the formation of entrepreneurial growth aspirations. Strategic Entrepreneurship Journal, 4(3), 234-251.

Basu, A., \& Goswami, A. (1999). Determinants of South Asian entrepreneurial growth in Britain: A multivariate analysis. Small Business Economics, 13(1), 57-70.

Baum, J. R. (1995). The relation of traits, competencies, motivation, strategy, and structure to venture growth. Frontiers of Entrepreneurship Research, 5, 13-21.

Belitski, M., Caiazza, R., \& Lehmann, E. E. (2021). Knowledge frontiers and boundaries in entrepreneurship research. Small Business Economics, 56, 521-531.

Belitski, M., \& Heron, K. (2017). Expanding entrepreneurship education ecosystems. Journal of Management Development, 36(2), 163-177.

Beresford, R., \& Michels, N. (2014). Embedding change through the entrepreneurial role of middle managers in the UK further education sector. Research in Post-Compulsory Education, 19(2), 147-164.

Bergek, A., \& Norrman, C. (2008). Incubator best practice: A framework. Technovation, 28(1-2), 20-28.

Berggren, E. (2017). Researchers as enablers of commercialization at an entrepreneurial university. Journal of Management Development, 36(2), 217-232.

Blanchflower, D. G., Oswald, A., \& Stutzer, A. (2001). Latent entrepreneurship across nations. European Economic Review, 45(4-6), 680-691.

Bleiklie, I., Enders, J., \& Lepori, B. (2017). Managing universities: Policy and organizational change from a western European comparative perspective. Palgrave Macmillan.

Boardman, C., \& Gray, D. (2010). The new science and engineering management: Cooperative research centers as government policies, industry strategies, and organizations. The Journal of Technology Transfer, 35(5), 445-459.

Bradley, S. R., Hayter, C. S., \& Link, A. N. (2013). Proof of concept centers in the United States: An exploratory look. The Journal of Technology Transfer, 38(4), 349-381.

Bratianu, C., \& Stanciu, S. (2010). An overview of present research related to entrepreneurial university. Management \& Marketing, 5(2), 117-134.

Bronstein, J., \& Reihlen, M. (2014). Entrepreneurial university archetypes: A meta-synthesis of case study literature. Industry and Higher Education, 28(4), 245-262.

Brush, C. G., Greene, P. G., \& Hart, M. M. (2001). From initial idea to unique advantage: The entrepreneurial challenge of constructing a resource base. Academy of Management Perspectives, 15(1), 64-78.

Caiazza, R., Belitski, M., \& Audretsch, D. B. (2020). From latent to emergent entrepreneurship: The knowledge spillover construction circle. The Journal of Technology Transfer, 45(3), 694-704.

Carl, J. and Menter, M. (2021) The social impact of universities: assessing the effects of the three university missions on social engagement. Studies in Higher Education, 1-12. https://doi.org/10.1080/03075079.2021.1896803. 
Carsrud, A., \& Brännback, M. (2011). Entrepreneurial motivations: What do we still need to know? Journal of Small Business Management, 49(1), 9-26.

Cassia, L., De Massis, A., Meoli, M., \& Minola, T. (2014). Entrepreneurship research centers around the world: Research orientation, knowledge transfer and performance. The Journal of Technology Transfer, 39(3), 376-392.

Civera, A., Lehmann, E. E., Paleari, S., \& Stockinger, S. A. E. (2020). Higher education policy: Why hope for quality when rewarding quantity? Research Policy, 49(8), 104083.

Clark, B. (2001). The entrepreneurial university: New foundations for collegiality, autonomy, and achievement. Higher Education Management, 13(2), 9-24.

Clark, W. W. (2003). Science parks: Practical and successful cases. International Journal of Technology Transfer and Commercialisation, 2, 179-206.

Cohen, S., \& Hochberg, Y. V. (2014). Accelerating start- ups: The seed accelerator phenomenon. SSRN Working Paper No. 2418000, Social Science Research Network. Available at https://papers.ssrn.com/sol3/papers.cfm?abstract_ $\mathrm{id}=2418000$.

Cunningham, J. A. and Golden, W. (2015). National innovation system of Ireland. Wiley Encyclopedia of Management, 1-14.

Cunningham, J. A., \& Link, A. N. (2021). Latent technology as an outcome of R\&D. Technological Forecasting and Social Change, 162, 120371.

Cunningham, J. A., \& Menter, M. (2021). Transformative change in higher education: Entrepreneurial universities and high-technology entrepreneurship. Industry and Innovation, 28(3), 343-364.

Cunningham, J. A., Guerrero, M., \& Urbano, D. (2017). Entrepreneurial universities-Overview, reflections, and future research agendas. In T. World \& D. Siegel (Eds.), Entrepreneurial Universities, Technology and Knowledge Transfer (pp. 3-19).

Cunningham, J. A., Menter, M., \& Young, C. (2017b). A review of qualitative case methods trends and themes used in technology transfer research. The Journal of Technology Transfer, 42(4), 923-956.

Cunningham, J. A., Harney, B., \& Fitzgerald, C. (2020). Effective technology transfer offices: A business model framework. Springer.

Davey, T., Rossano, S., \& Van der Sijde, P. (2016). Does context matter in academic entrepreneurship? The role of barriers and drivers in the regional and national context. The Journal of Technology Transfer, 41(6), 1457-1482.

Davidsson, P. (1989). Entrepreneurship — and after? A study of growth willingness in small firms. Journal of Business Venturing, 4(3), 211-226.

Davidsson, P., \& Honig, B. (2003). The role of social and human capital among nascent entrepreneurs. Journal of Business Venturing, 18(3), 301-331.

De Silva, M. (2016). Academic entrepreneurship and traditional academic duties: Synergy or rivalry? Studies in Higher Education, 41(12), 2169-2183.

Delmar, F., \& Wiklund, J. (2008). The effect of small business managers' growth motivation on firm growth: A longitudinal study. Entrepreneurship Theory and Practice, 32(3), 437-457.

Dolan, B., Cunningham, J. A., Menter, M., \& McGregor, C. (2019). The role and function of cooperative research centres in entrepreneurial universities: A micro level perspective. Management Decision, 57(12), 3406-3425.

Donina, D., Seeber, M., \& Paleari, S. (2017). Inconsistencies in the governance of interdisciplinarity: The case of the Italian higher education system. Science and Public Policy, 44(6), 865-875.

Dooley, L., \& Kirk, D. (2007). University-industry collaboration: Grafting the entrepreneurial paradigm onto academic structures. European Journal of Innovation Management, 10(3), 316-332.

Duruflé, G., Hellmann, T., \& Wilson, K. (2018). Catalysing entrepreneurship in and around universities. Oxford Review of Economic Policy, 34(4), 615-636.

Estrin, S., Korosteleva, J., \& Mickiewicz, T. (2013). Which institutions encourage entrepreneurial growth aspirations? Journal of Business Venturing, 28(4), 564-580.

Etzkowitz, H. (2003). Research groups as 'quasi-firms': The invention of the entrepreneurial university. Research Policy, 32(1), 109-121.

Etzkowitz, H., Webster, A., Gebhardt, C., \& Terra, B. R. C. (2000). The future of the university and the university of the future: Evolution of ivory tower to entrepreneurial paradigm. Research Policy, 29(2), 313-330.

Fitzgerald, C., Cunningham, J. A., Menter, M. \& Nyuur, R. B. (2021) Strategy processes in technology transfer offices: Antecedents and consequences. In: D. Mietzner \& C. Schultz (eds). New Perspectives in Technology Transfer. Springer, pp. 71-87.

Forliano, C., De Bernardi, P., \& Yahiaoui, D. (2021). Entrepreneurial universities: A bibliometric analysis within the business and management domains. Technological Forecasting and Social Change, 165, 120522.

Formica, P. (2002). Entrepreneurial universities: The value of education in encouraging entrepreneurship. Industry and Higher Education, 16(3), 167-175.

Freytag, A., \& Thurik, R. (2007). Entrepreneurship and its determinants in a cross-country setting. Journal of Evolutionary Economics, 17(2), 117-131.

Gaibraith, J. (1982). The stages of growth. Journal of Business Strategy, 3(1), 70-79.

Garrett-Jones, S., Turpin, T., \& Diment, K. (2010). Managing competition between individual and organizational goals in cross-sector research and development centres. The Journal of Technology Transfer, 35(5), 527-546.

Gibb, A., \& Hannon, P. (2005). Towards the entrepreneurial university. International Journal of Entrepreneurship Education, 4(1), 73-93.

Goldstein, H. A. (2010). The 'entrepreneurial turn' and regional economic development mission of universities. The Annals of Regional Science, 44(1), 83-109.

Graf, H. and Menter, M. (2021). Public research and the quality of inventions: The role and impact of entrepreneurial universities and regional network embeddedness. Small Business Economics, 1-18. https://doi.org/10.1007/ s11187-021-00465-w.

Grillitsch, M. (2018). Place-based entrepreneurship and innovation policy for industrial diversification (No. 2018/3). 
Lund University, CIRCLE-Center for Innovation, Research and Competences in the Learning Economy.

Grilo, I., \& Thurik, R. (2005). Latent and actual entrepreneurship in Europe and the US: Some recent developments. The International Entrepreneurship and Management Journal, 1(4), 441-459.

Grimaldi, R., \& Grandi, A. (2005). Business incubators and new venture creation: An assessment of incubating models. Technovation, 25(2), 111-121.

Guerrero, M., \& Urbano, D. (2012). The development of an entrepreneurial university. The Journal of Technology Transfer, 37(1), 43-74.

Guerrero, M., Urbano, D., Cunningham, J. A., \& Organ, D. (2014). Entrepreneurial universities in two European regions: A case study comparison. The Journal of Technology Transfer, 39(3), 415-434.

Guerrero, M., Urbano, D., \& Fayolle, A. (2016). Entrepreneurial activity and regional competitiveness: Evidence from European entrepreneurial universities. The Journal of Technology Transfer, 41(1), 105-131.

Gunasekara, C. (2006). Reframing the role of universities in the development of regional innovation systems. The Journal of Technology Transfer, 31(1), 101-113.

Gundry, L. K., \& Welsch, H. P. (2001). The ambitious entrepreneur: High growth strategies of women-owned enterprises. Journal of Business Venturing, 16(5), 453-470.

Hannon, P. D. (2013). Why is the entrepreneurial university important? Journal of Innovation Management, 1(2), $10-17$.

Hausberg, J. P., \& Korreck, S. (2020). Business incubators and accelerators: A co-citation analysis-based, systematic literature review. The Journal of Technology Transfer, 45(1), 151-176.

Haynie, J. M., Shepherd, D., Mosakowski, E., \& Earley, P. C. (2010). A situated metacognitive model of the entrepreneurial mindset. Journal of Business Venturing, 25(2), 217-229.

Hayter, C. S., \& Link, A. N. (2015). On the economic impact of university proof of concept centers. The Journal of Technology Transfer, 40(1), 178-183.

Hechavarria, D. M., Renko, M., \& Matthews, C. H. (2012). The nascent entrepreneurship hub: goals, entrepreneurial self-efficacy and start-up outcomes. Small Business Economics, 39(3), 685-701.

Herron, L., \& Sapienza, H. J. (1992). The entrepreneur and the initiation of new venture launch activities. Entrepreneurship Theory and Practice, 17(1), 49-55.

Hülsbeck, M., Lehmann, E. E., \& Starnecker, A. (2013). Performance of technology transfer offices in Germany. The Journal of Technology Transfer, 38(3), 199-215.

Jain, S., George, G., \& Maltarich, M. (2009). Academics or entrepreneurs? Investigating role identity modification of university scientists involved in commercialization activity. Research Policy, 38(6), 922-935.

Kalar, B., \& Antoncic, B. (2015). The entrepreneurial university, academic activities and technology and knowledge transfer in four European countries. Technovation, 36-37, $1-11$.

Khurana, I., \& Dutta, D. K. (2021). From latent to emergent entrepreneurship in innovation ecosystems: The role of entrepreneurial learning. Technological Forecasting and Social Change, 167, 120694.

Kirby, D. A. (2006). Creating entrepreneurial universities in the UK: Applying entrepreneurship theory to practice. The Journal of Technology Transfer, 31(5), 599-603.

Klofsten, M. (2000). Training entrepreneurship at universities: A Swedish case. Journal of European Industrial Training, 24(6), 337-344.

Klofsten, M., Fayolle, A., Guerrero, M., Mia, S., Urbano, D., \& Wright, M. (2019). The entrepreneurial university as driver for economic growth and social change-Key strategic challenges. Technological Forecasting and Social Change, 141, 149-158.

Kuratko, D. F., \& Menter, M. (2017). The role of public policy in fostering technology-based nascent entrepreneurship. In J. A. Cunningham \& C. O'Kane (Eds.), Technologybased nascent entrepreneurship (pp. 19-52). Palgrave Macmillan.

Larsson, J. P., Wennberg, K., Wiklund, J., \& Wright, M. (2017). Location choices of graduate entrepreneurs. Research Policy, 46(8), 1490-1504.

Lazzeretti, L., \& Tavoletti, E. (2005). Higher education excellence and local economic development: The case of the entrepreneurial university of Twente. European Planning Studies, 13(3), 475-493.

Lehmann, E. E., \& Menter, M. (2016). University-industry collaboration and regional wealth. The Journal of Technology Transfer, 41(6), 1284-1307.

Levie, J., \& Lichtenstein, B. B. (2010). A terminal assessment of stages theory: Introducing a dynamic states approach to entrepreneurship. Entrepreneurship Theory and Practice, 34(2), 317-350.

Lewis, V. L., \& Churchill, N. C. (1983). The five stages of small business growth. Harvard Business Review, 61(3), $30-50$.

Li, J., Qu, J., \& Huang, Q. (2018). Why are some graduate entrepreneurs more innovative than others? The effect of human capital, psychological factor and entrepreneurial rewards on entrepreneurial innovativeness. Entrepreneurship \& Regional Development, 30(5-6), 479-501.

Lichtenstein, B. B., Carter, N. M., Dooley, K. J., \& Gartner, W. B. (2007). Complexity dynamics of nascent entrepreneurship. Journal of Business Venturing, 22(2), 236-261.

Link, A. N., \& Scott, J. T. (2015). Research, science, and technology parks. In A. N. Link, D. S. Siegel, \& M. Wright (Eds.), The Chicago Handbook of University Technology Transfer and Academic Entrepreneurship (pp. 168-187). University of Chicago Press.

Littunen, H., \& Niittykangas, H. (2010). The rapid growth of young firms during various stages of entrepreneurship. Journal of Small Business and Enterprise Development, 17(1), 8-31.

Maas, G., \& Jones, P. (2017). Entrepreneurship centres: Global perspectives on their contributions to higher education institutions. Springer.

Markuerkiaga, L., Errasti, N., \& Igartua, J. I. (2014). Success factors for managing an entrepreneurial university: Developing an integrative framework. Industry and Higher Education, 28(4), 233-244.

Martin, L. M., Warren-Smith, I., \& Lord, G. (2019). Entrepreneurial architecture in UK universities: Still a work 
in progress? International Journal of Entrepreneurial Behavior \& Research, 25(2), 281-297.

Massey, D., \& Wield, D. (2003). High-tech fantasies: Science parks in society, science and space. Routledge.

Masuda, T. (2006). The determinants of latent entrepreneurship in Japan. Small Business Economics, 26(3), 227-240.

Matlay, H. (2008). The impact of entrepreneurship education on entrepreneurial outcomes. Journal of Small Business and Enterprise Development, 15(2), 382-396.

McAdam, M., \& Cunningham, J. A. (2019). Entrepreneurial behaviour: A research outlook. In M. McAdam \& J. A. Cunningham (Eds.), Entrepreneurial behaviour (pp. 1-13). Palgrave Macmillan.

Menter, M., Lehmann, E. E., \& Klarl, T. (2018). In search of excellence: A case study of the first excellence initiative of Germany. Journal of Business Economics, 88(9), $1105-1132$.

Menzies, T. V. (2000). An exploratory study of university entrepreneurship centres in Canada: A first step in model buildings. Journal of Small Business \& Entrepreneurship, 15(3), 15-38.

Mian, S. A. (1996). Assessing value-added contributions of university technology business incubators to tenant firms. Research Policy, 25(3), 325-335.

Mian, S. A. (1997). Assessing and managing the university technology business incubator: An integrative framework. Journal of Business Venturing, 12(4), 251-285.

Miller, K., Alexander, A., Cunningham, J. A., \& Albats, E. (2018). Entrepreneurial academics and academic entrepreneurs: A systematic literature review. International Journal of Technology Management, 77(1-3), 9-37.

Miller, K., Cunningham, J. A. and Lehmann, E. E. (2021). Extending the university mission and business model: Influences and implications. Studies in Higher Education, 1-11. https://doi.org/10.1080/03075079.2021.1896799.

Moog, P., Werner, A., Houweling, S., \& Backes-Gellner, U. (2015). The impact of skills, working time allocation and peer effects on the entrepreneurial intentions of scientists. The Journal of Technology Transfer, 40(3), 493-511.

Morris, M., Schindehutte, M., \& Allen, J. (2005). The entrepreneur's business model: toward a unified perspective. Journal of Business Research, 58(6), 726-735.

Morris, M. H., Shirokova, G., \& Tsukanova, T. (2017). Student entrepreneurship and the university ecosystem: A multi-country empirical exploration. European Journal of International Management, 11(1), 65-85.

Murnieks, C. Y., Mosakowski, E., \& Cardon, M. S. (2014). Pathways of passion: Identity centrality, passion, and behavior among entrepreneurs. Journal of Management, 40(6), 1583-1606.

Nelles, J. and Vorley, T. (2008). Entrepreneurial architecture in UK higher education institutions: Consolidating the third mission. In DRUID, 25th Celebration Conference (pp. 18-20).

Nelles, J., \& Vorley, T. (2010). Constructing an entrepreneurial architecture: An emergent framework for studying the contemporary university beyond the entrepreneurial turn. Innovative Higher Education, 35(3), 161-176.

Nicotra, M., Del Giudice, M. and Romano, M. (2021). Fulfilling university third mission: Towards an ecosystemic strategy of entrepreneurship education. Studies in Higher
Education, 1-11. https://doi.org/10.1080/03075079.2021. 1896806.

Norton, W. I., \& Moore, W. T. (2002). Entrepreneurial risk: Have we been asking the wrong question? Small Business Economics, 18(4), 281-287.

Nurmi, P., \& Paasio, K. (2007). Entrepreneurship in Finnish universities. Education+ Training, 49(1), 56-65.

O'Kane, C., Mangematin, V., Zhang, J. A., \& Cunningham, J. A. (2020). How university-based principal investigators shape a hybrid role identity. Technological Forecasting and Social Change, 159, 120179.

O'Kane, C., Zhang, J. A., Cunningham, J. A., \& O'Reilly, P. (2017). What factors inhibit publicly funded principal investigators' commercialization activities? Small Enterprise Research, 24(3), 215-232.

O’Reilly, N. M., Robbins, P., \& Scanlan, J. (2019). Dynamic capabilities and the entrepreneurial university: A perspective on the knowledge transfer capabilities of universities. Journal of Small Business \& Entrepreneurship, 31(3), 1-21.

Parakhina, V., Godina, O., Boris, O., \& Ushvitsky, L. (2017). Strategic management in universities as a factor of their global competitiveness. International Journal of Educational Management, 31(1), 62-75.

Pauwels, C., Clarysse, B., Wright, M., \& Van Hove, J. (2016). Understanding a new generation incubation model: The accelerator. Technovation, 50, 13-24.

Phan, P. H., Siegel, D. S., \& Wright, M. (2005). Science parks and incubators: Observations, synthesis and future research. Journal of Business Venturing, 20(2), 165-182.

Roberts, P. (2004). The modern firm. Oxford University Press.

Sandberg, W. R., \& Gatewood, E. J. (1991). A profile of entrepreneurship research centers: Orientations, interests, activities, and resources. Entrepreneurship Theory and Practice, 15(3), 11-24.

Santos, S. C., Curral, L., \& Caetano, A. (2010). Cognitive maps in early entrepreneurship stages: From motivation to implementation. The International Journal of Entrepreneurship and Innovation, 11(1), 29-44.

Schulte, P. (2004). The entrepreneurial university: A strategy for institutional development. Higher Education in Europe, 29(2), 187-191.

Sexton, D. L., Upton, N. B., Wacholtz, L. E., \& McDougall, P. P. (1997). Learning needs of growth-oriented entrepreneurs. Journal of Business Venturing, 12(1), 1-8.

Siegel, D. S., Waldman, D., \& Link, A. (2003a). Assessing the impact of organizational practices on the relative productivity of university technology transfer offices: An exploratory study. Research Policy, 32(1), 27-48.

Siegel, D. S., Wessner, C., Binks, M., \& Lockett, A. (2003b). Policies promoting innovation in small firms: Evidence from the US and UK. Small Business Economics, 20(2), 121-127.

Swaen, V., de Woot, P., \& de Callatay, D. (2011). The business school of the twenty-first century: Educating citizens to address the new world challenges. In M. Morsing \& S. Rovira (Eds.), Business schools and their contribution to society (pp. 175-192). Sage.

Ucbasaran, D., Westhead, P., Wright, M., \& Binks, M. (2003). Does entrepreneurial experience influence opportunity identification? The Journal of Private Equity, 7(1), 7-14. 
Van Auken, H. E. (1999). Obstacles to business launch. Journal of Developmental Entrepreneurship, 4(2), 175-187.

Vorley, T., \& Nelles, J. (2009). Building entrepreneurial architectures: A conceptual interpretation of the third mission. Policy Futures in Education, 7(3), 284-296.

Wagner, M., Schaltegger, S., Hansen, E. G., \& Fichter, K. (2021). University-linked programmes for sustainable entrepreneurship and regional development: How and with what impact? Small Business Economics, 56, 1141-1158.

Walsh, G. S., \& Cunningham, J. A. (2016). Business failure and entrepreneurship: Emergence, evolution and future research. Foundations and Trends ${ }^{\circledR}$ in Entrepreneurship, 12(3), 163-285.

Washer, P. (2007). Revisiting key skills: A practical framework for higher education. Quality in Higher Education, 13(1), 57-67.
Watson, K., McGowan, P., \& Cunningham, J. A. (2018). An exploration of the business plan competition as a methodology for effective nascent entrepreneurial learning. International Journal of Entrepreneurial Behavior \& Research, 24(1), 121-146.

Wennekers, S., van Stel, A., Thurik, R., \& Reynolds, P. (2005). Nascent entrepreneurship and the level of economic development. Small Business Economics, 24(3), 293.

Publisher's note Springer Nature remains neutral with regard to jurisdictional claims in published maps and institutional affiliations. 